DOI https://doi.org/10.30929/2307-9770.2020.08.04.02

UDC 37.018.1.064-055.52-055.62:316.647.5

\title{
Substantiation of pedagogical conditions of tolerant attitude of school and family to children of primary school age
}

\author{
Liulka H. A. ${ }^{*}$ \\ Poltavskyi natsionalnyi pedahohichnyi universytet im. V. H. Korolenka, Poltava, Ukraine
}

Received: $15.09 .2020 \quad$ Accepted: 25.12 .2020

\begin{abstract}
In the Concept of the New Ukrainian School, the main task of a modern secondary school is the education of conscious citizens of Ukraine, providing conditions for creative self-realization and self-determination of the individual. Changes and updates of the educational paradigm bring teachers to a modern understanding of the educational process as an activity based on self-development, self-improvement and their pedagogical support. It involves subject-object interaction in the educational space of the secondary school. One of its important components is the pedagogical conditions, compliance with which depends on the effectiveness of achieving the educational goal. The study of this problem is carried out in several areas: the role of pedagogical conditions for the formation and development of the personality of both the teacher and the subject to which the learning process is directed; organization, activation and modernization of subject training. The analysis allows us to state that the modern understanding of the concept of "pedagogical conditions" is complicated by the variety of research areas of scientists. Analysis of pedagogical, psychological and philosophical scientific literature shows that the problem of substantive and substantive analysis of the concept of pedagogical conditions is considered by scientists from different aspects. In the context of our study, we define pedagogical conditions as features of the organization of the educational process in a secondary school, which determine the results of upbringing, education and development of the student's personality, objectively ensuring the possibility of achieving them. In the course of our research the levels of pedagogical conditions were determined. Thus, considering the concept of pedagogical conditions in the context of educational activities of a secondary school, we came to the conclusion that pedagogical conditions are a qualitative characteristic of the main factors, processes and phenomena of the educational environment. Research in the direction of development of technologies of creation of optimum pedagogical conditions for the decision of certain problems of educational activity of comprehensive school is perspective.

Key words: pedagogical conditions, tolerant attitude, teacher-student interaction, levels of tolerant attitude.
\end{abstract}

\section{Обґрунтування педагогічних умов толерантного ставлення школи і сім'ї до дітей молодшого шкільного віку}

\author{
Люлька Г. А. \\ Полтавський національний педагогічний університет імені В. Г. Короленка, Полтава, Україна
}

\begin{abstract}
Анотація. У Концепції Нової української школи основним завданням сучасного загальноосвітнього навчального закладу називається виховання свідомих громадян України, забезпечення умов для творчої самореалізації і самовизначення особистості. Зміни й оновлення освітньої парадигми підводять педагогів до сучасного розуміння навчально-виховного процесу як діяльності, що базується на саморозвитку, самовдосконаленні та їх педагогічній підтримці. Вона передбачає суб'єктно-об'єктну взаємодію у навчальновиховному «просторі» загальноосвітнього навчального закладу. Однією із важливих його складових $€$ педагогічні умови, від дотримання яких залежить ефрективність досягнення поставленої освітньої мети. Дослідження даної проблеми здійснюється за кількома напрямами: роль педагогічних умов для формування і розвитку особистості як педагога, так і суб'єкта, на який спрямовано процес навчання; організації, активізації та модернізації предметної підготовки. Проведений аналіз дозволяє констатувати про те, що сучасне розуміння поняття «педагогічні умови» ускладнюється різноманіттям напрямів досліджень науковців. Аналіз педагогічної, психологічної та філософрської наукової літератури свідчить про те, що проблема сутнісного та
\end{abstract}

\footnotetext{
Corresponding Author: Liulka Hanna Andriivna. Tel. (095)-911-7-222. E-mail: annalulka61092@ukr.net Poltavskyi natsionalnyi pedahohichnyi universytet im. V. H. Korolenka, vul. Ostrogradskoho, 2, Poltava, Ukraine, lндекс. 36003

Відповідальний автор: Люлька Ганна Андріївна. Тел. (095)-911-7-222. E-mail: annalulka61092@ukr.net Полтавський національний педагогічний університет імені В. Г. Короленка. вул. Остроградського, 2, Полтава, Україна, Індекс. 36003
} 
змістового аналізу поняття педагогічних умов розглядається вченими з різних аспектів. У контексті нашого дослідження ми визначаємо педагогічні умови як особливості організації навчально-виховного процесу у загальноосвітньому навчальному закладі, що детермінують результати виховання, освіти та розвитку особистості учня, об'єктивно забезпечуючи можливість їх досягнення. У процесі нашого дослідження були визначені рівні педагогічних умов. Отже, розглядаючи поняття педагогічних умов в контексті навчальновиховної діяльності загальноосвітнього навчального закладу, ми дійшли висновку, що педагогічні умови $\epsilon$ якісною характеристикою основних фракторів, процесів і явищ освітнього середовища. Перспективними $\epsilon$ дослідження за напрямом розробок технологій створення оптимальних педагогічних умов для розв'язання певних завдань навчально-виховної діяльності загальноосвітнього навчального закладу.

Ключові слова: педагогічні умови, толерантне ставлення, взаємодія вчителя та учні, рівні толерантного ставлення.

\title{
Обоснование педагогических условий толерантного отношения школы и семьи к детям младшего школьного возраста
}

\author{
Люлька А. А.
}

Полтавский национальный педагогический университет имени В. Г. Короленко, Полтава, Украина

\begin{abstract}
Аннотация. В Концепции Новой украинской школы основной задачей современного общеобразовательного учебного заведения называется воспитания сознательных граждан Украины, обеспечения условий для творческой самореализации и самоопределения личности. Изменения и обновления образовательной парадигмы подводят педагогов к современному пониманию учебно-воспитательного процесса как деятельности, основанной на саморазвитии, самосовершенствовании и их педагогической поддержке. Она предусматривает субъектно-объектную взаимодействие в учебно-воспитательном «пространстве» общеобразовательного учебного заведения. Одной из важных его составляющих являются педагогические условия, от соблюдения которых зависит эффективность достижения поставленной образовательной цели. Исследование данной проблемы осуществляется по нескольким направлениям: роль педагогических условий для формирования и развития личности как педагога, так и субъекта, на который направлено процесс обучения; организации, активизации и модернизации предметной подготовки. Проведенный анализ позволяет констатировать о том, что современное понимание понятия «педагогические условия» осложняется многообразием направлений исследований ученых. Анализ педагогической, психологической и философской научной литературы свидетельствует о том, что проблема сущностного и содержательного анализа понятия педагогических условий рассматривается учеными из разных аспектов. В контексте нашего исследования мы определяем педагогические условия как особенности организации учебно-воспитательного процесса в общеобразовательном учебном заведении, детерминирующих результаты воспитания, образования и развития личности ученика, объективно обеспечивая возможность их достижения. В процессе нашего исследования были определены уровни педагогических условий. Итак, рассматривая понятие педагогических условий в контексте учебной деятельности общеобразовательного учебного заведения, мы пришли к выводу, что педагогические условия являются качественной характеристикой основных фракторов, процессов и явлений образовательной среды. Перспективными являются исследования по направлению разработок технологий создания оптимальных педагогических условий для решения определенных задач учебно-воспитательной деятельности общеобразовательного учебного заведения.

Ключевые слова: педагогические условия, толерантное отношение, взаимодействие учителя и ученики, уровне толерантного отношения..
\end{abstract}

\section{Bcmyn}

Однією із важливих його складових $€$ педагогічні умови, від дотримання яких залежить ефективність досягнення поставленої освітньої мети. Дослідження даної проблеми здійснюється за кількома напрямами: роль педагогічних умов для формування і розвитку особистості як педагога, так і суб'єкта, на який спрямовано процес навчання (С. Андрєєв, М. Вохришева, А. Гречихін, Е. Медвєдєва та ін.); організації, активізації та модернізації предметної підготовки (Г. Алексєєва, Р. Жариков, М. Коляда та ін.).

3'ясовано сутність понять дослідження, які умовно скомпоновано у два блоки. Ряд вчених досліджували процес виховання толерантних взаємостосунків у молодших школярів (А. Бистрюкова, О. Біда, М. Гайдур, О. Гуренко, І. Казанжи, О. Комар, О. Кондратьєва, Л. Кондрашова, Л. Костюченко, С. Мартиненко, О. Матвієнко, О. Овчаренко, Н. Теличко, О. Філіпп'єва, Л. Хомич, Ю. Шаповал та ін.). Інші дослідники - педагогічні умови толерантного ставлення школи і сім'ї до молодших школярів (І. Бех, Н. 
Бібік, О. Богданова, Т. Варенко, В. Калошин, С. Кара, О. Кононко, О. Савченко, Ю. Тодоровцева та ін.). Усе це дозволяє стверджувати, що тезаурус нашого дослідження є певною змістовою основою процесу формування толерантного ставлення до молодших школярів.

У педагогічній літературі поняття «педагогічні умови» трактується як видова категорія педагогічної системи. Так, Б. Купріянова педагогічні умови розглядає як сукупність об'єктивних можливостей змісту, форм, методів і прийомів підвищення ефективності навчально-виховного процесу і матеріальнопросторового середовища, що забезпечують успішне вирішення поставлених і проектованих у дослідженні завдань. Н. Тверезовська описує педагогічні умови як необхідні міри, що сприяють успішності навчання на основі педагогічної підтримки (Tverezovska, 2009, p.90-92).

У контексті нашого дослідження ми визначаємо педагогічні умови як особливості організації навчально-виховного процесу у загальноосвітньому навчальному закладі, що детермінують результати виховання, освіти та розвитку особистості учня, об'єктивно забезпечуючи можливість їх досягнення.

Meта роботи: дослідити педагогічні умови формування толерантного ставлення батьків та вчителів до дітей молодшого шкільного віку, охарактеризувати зміст, форми та методи толерантного ставлення школи та сім'ї до учнів початкових класів.

\section{II Матеріал і методи дослідження}

У вітчизняній педагогіці виділено кілька рівнів педагогічних умов.

Перший рівень педагогічних умов - це особистісні характеристики учнів, які детермінують успішність протікання навчально-виховного процесу.

Другий рівень педагогічних умов - безпосередні обставини реалізації процесу навчання і виховання, а саме педагогічні умови змісту та організації діяльності учнів; міжособистісних відносин, спілкування в класі; взаємовідносин педагогів з учнями; адаптація школярів до освітнього середовища школи; взаємодії загальноосвітнього навчального закладу з навколишнім середовищем та iн (Lyulka, 2020). Саме другий рівень педагогічних умов являє собою свого роду проекцію обставин навчальновиховного процесу школи на суб'єктивний світ учня. Тобто, в якості педагогічної умови може розглядатися суб'єктивне сприйняття школярем навчально-виховної, дослідницько-пошукової, громадсько-корисної діяльності, міжособистісних відносин, соціальних взаємодій. Визначальним стає підготовленість особистості учня до вирішення поставлених завдань, його внутрішня мотивація та система ціннісних орієнтацій (Bozhovich, 1972). Розуміючи під якістю навчально-виховної діяльності загальноосвітнього закладу результати, в яких відображено досягнутий рівень мети та виконання завдань навчання і виховання, динаміку особистісного розвитку школяра, його соціального інтелекту та соціальної активності, рівень особистих зусиль з отримання знань, умінь і навичок, зміни професійної компетентності педагога та його ставлення до роботи та учнів, упровадження й використання сучасних педагогічних технологій, вважаємо, що їі підвищенню сприятиме сукупність таких педагогічних умов, як:

- с сформованість мотиваційної основи навчання учнів;

- забезпечення їх активної креативної діяльності шляхом впровадження особистісноорієнтованого, компетентнісного та діяльнісного підходів;

- використання педагогічної рефлексії вчителів;

- наявність алгоритму дій педагога;

- діагностика ефективності навчання і виховання тощо (Voitovych, 2013 р. 1-24).

Розглядаючи поняття педагогічних умов в контексті навчально-виховної діяльності загальноосвітнього навчального закладу, ми дійшли висновку, що педагогічні умови $є$ якісною характеристикою основних факторів, процесів і явищ освітнього середовища. Перспективними $\epsilon$ дослідження за напрямом розробок технологій створення оптимальних педагогічних умов для розв'язання певних завдань навчально-виховної діяльності загальноосвітнього навчального закладу.

Багато соціальних проблем дестабілізують важливі функції сім'ї та знижують ії здатність адаптуватися до нових умов. Тому однією з ознак толерантних стосунків $є$ активна взаємодія батьків і дітей з виразом взаємоповаги та підтримки. У зв'язку з цим вчитель повинен цілеспрямовано працювати з батьками учнів та пояснювати важливість дотримання принципів толерантності у спілкуванні з дітьми [12]. Регулювання відносин між батьками та дітьми, що сприяє формуванню толерантності у взаємодіючих частинах, означає: 
$\checkmark$ вивчення стану, моніторинг результатів взаємодії батько-дитина;

$\checkmark$ виявлення труднощів, проблем сімейної взаємодії та вибір навчальних методів їх регулювання;

$\checkmark$ організація вивчення та узагальнення належної практики взаємодії батько-дитина;

$\checkmark$ навчання учнів та батьків спільній діяльності та ефективному спілкуванню;

$\checkmark$ створення психологічного клімату, сприятливого для створення тісних контактів між батьками та дітьми в організації спільної діяльності (Liulka, 2020 р. 72).

Педагог повинен враховувати різні чинники, включаючи тип сім'ї, наявність у сім'ї кількох поколінь, вік дітей, соціальний статус сім'ї, місцеве середовище сім'ї, проблеми сім'ї (Onysiuk, O. 2001) Діяльність вчителя навколо толерантності у стосунках з дітьми та батьками включають такі кроки:

$\checkmark$ підготовча або діагностична, під час якої визначається початковий рівень проблеми толерантності у сімейних стосунках;

$\checkmark$ мета, що означає встановлення цілей та завдань для навчання толерантності у відносинах між дітьми та батьками за результатами їх дослідження;

$\checkmark$ процедурні - шляхи, методи та прийоми становлення толерантних відносин між батьками та дітьми, використання конкретних прийомів,

$\checkmark$ індивідуальна робота з сім'єю, робота з кількома сім'ями, які мають подібні або діаметрально протилежні проблеми (Piren, 2014);

$\checkmark$ підсумок: порівняння результату з очікуваним, висновки щодо прогресу, досягнутого у досягненні цілей та інформація, обговорення перспективи подальшої співпраці (Artemenko, N, 2012)..

Тому проблема формування толерантності у відносинах батьки та діти складна та багатогранна, для ефективного рішення яких потрібен вчитель всебічного підходу. Це передбачає розвиток стосунків та спілкування в сім'ї, набуття знань батьками, щодо толерантності як найважливішої цінності суспільства та воля, якою керуються знання, набуті в їхній поведінці. Оптимальне вивчення та регулювання толерантних стосунків між батьками та дітьми можливі при організації діяльності вчителів, учнів та батьків [16].

Ми підкреслюємо, що до основних складових толерантності дітей молодшого шкільного віку належать: знання толерантності, знання існування відмінностей у культурах та способах мислення про інший етнічний, національний чи культурний фон; формування доброзичливого ставлення до іншої людини, а також зацікавленість в отриманні певного досвіду спілкування з представниками іншої культури; розвитку навичок культурного спілкування та навичок вирішення конфліктів. Таким чином, знання існування толерантності, набутої дітьми молодшого шкільного віку, допомагає переконати їх у тому, що доцільно приймати певні рішення та дії щодо іншої людини, усвідомлювати та керуватися власними почуттями. Слід зазначити, що процес формування толерантності не обмежується наповненням дітей молодшого шкільного віку знаннями про толерантність; та прийнятті позиції інших.

\section{III Результати}

Ми проаналізували, що у педагогічній літературі поняття «педагогічні умови» трактується як видова категорія педагогічної системи. У контексті нашого дослідження ми визначаємо педагогічні умови як особливості організації навчально-виховного процесу у загальноосвітньому навчальному закладі, що детермінують результати виховання, освіти та розвитку особистості учня, об'єктивно забезпечуючи можливість їх досягнення.

Охарактеризували, що толерантна взаємодія між вчителем і учнями визначається чотирма основними параметрами:

$\checkmark$ діалогом,

$\checkmark$ співпрацею,

$\checkmark$ опікою,

$\checkmark$ пробаченням.

Саме розглядаючи поняття педагогічних умов у контексті навчально-виховної діяльності загальноосвітнього навчального закладу, ми дійшли висновку, що педагогічні умови $€$ якісною характеристикою основних факторів, процесів і явищ освітнього середовища.

У структурі толерантності нами виділено такі компоненти:

$\checkmark$ психофізіологічний, 
$\checkmark$ мотиваційну цінність,

$\checkmark$ етико-комунікативний,

$\checkmark$ емоційно-емпатичний,

$\checkmark$ когнітивний,

$\checkmark$ поведінковий,

$\checkmark$ рефрлексивний.

Метою формування толерантності у дітей початкової школи є розвиток толерантних особистісних ознак у цій віковій групі. Цього можна досягти лише завдяки взаємодії школи та батьків.

У житті дитини школа та сім'я - це два найважливіші фрактори, і вони повинні спільно працювати задля досягнення мети та вирішення таких завдань, як:

$\checkmark$ запобігання нетерпимості у класі;

$\checkmark$ створення атмосфери діалогу та співпраці під час спілкування;

$\checkmark$ формування бажання зрозуміти іншого;

$\checkmark$ розвитку здатності бути критичними до власної діяльності та поведінки;

$\checkmark$ розвитку здатності до емпатії та співпереживання,

$\checkmark$ довіри та гідності.

\section{IV Обговорення}

Проблеми толерантності осмислюються у працях таких авторів, як: О. Бабчук, І. Бех, Л. Вишневська, Р. Войтович [12], Н. Гончарук [1], О. Грива [21], О. Гуменюк, О. Долгополова, О. Майборода, Т. Пилипенко, О. Сараєва, П. Степанов, О. Тишков, А. Фурман, Р. Чачалова, В. Шалін [118], Ю. Шаюк та ін. Сучасні уявлення про толерантність багато в чому визначені думками гуманістів епохи Відродження (Ф. Рабле, Т. Мор, М. Монтень, Е. Роттердамський та ін.).

Дані статті присвячені аналізу розвитку ідей толерантності в історії освіти та педагогічної думки України. Висвітлюються ідеї толерантності в культурній спадщині відомих діячів України. Виноситься проблема зв'язку толерантності до невизначеності 3 креативністю розглядається в контексті психологічних особливостей викладачів вищої школи. Розглядаються основні контексти інтернаціоналізації у вищій школі та пов'язані з нею окремі аспекти виховання патріотизму в умовах інтенсифікації міжкультурної взаємодії. Авторами порушено низку проблем, пов'язаних з ризиками міжнаціональних конфліктів, мовного бар'єру і в цілому складної адаптації іноземних студентів. Отримані дані можуть бути використані для прийняття управлінських рішень в вузах, навчальних іноземних громадян. Але не було висвітлено проблем формування толерантних відносин у сім'ї. адже процес формування особистості носить у собі витоки сімейного начала. Також не проаналізовано роль вчителя у вихованні особистості школяра. Відсутні умови формування толерантного ставлення вчителів та батьків до дітей молодшого шкільного віку.

\section{V Висновки}

Нами підкреслено, що до основних складових толерантності дітей молодшого шкільного віку належать: знання толерантності, знання існування відмінностей у культурах та способах мислення про інший етнічний, національний чи культурний фон; формування доброзичливого ставлення до іншої людини, а також зацікавленість в отриманні певного досвіду спілкування з представниками іншої культури; розвитку навичок культурного спілкування та навичок вирішення конфліктів. Таким чином, знання існування толерантності, набутої дітьми молодшого шкільного віку, допомагає переконати їх у тому, що доцільно приймати певні рішення та дії щодо іншої людини, усвідомлювати та керуватися власними почуттями. Слід зазначити, що процес формування толерантності не обмежується наповненням дітей молодшого шкільного віку знаннями про толерантність; та прийнятті позиції інших. Перспективними $є$ дослідження за напрямом розробок технологій створення оптимальних педагогічних умов для розв'язання певних завдань навчально-виховної діяльності загальноосвітнього навчального закладу. 


\section{Бібліографічні посилання}

1. Lyapunova V. Origins of the development of ideas of tolerance in Ukraine // Cambridge Journal of Education and Science. 2016. № 1 (15). C.6-491. https://elibrary.ru/contents.asp?id=41196356

2. Varetska O. Personal and Professional Component of Primary School Teachers' Social Competence: its Development in Postgraduate Education // Personal and Professional Component of Primary School Teachers' Social Competence: its Development in Postgraduate Education. 2017. № 8. C.104-115. http://dspace.pdpu.edu.ua/jspui/handle/123456789/6428

3. Kornilova T.V., Smirnov S.D. Tolerance towards ambiguity and creativity in students and teachers // Psychology in Russia: State of the Art. 2018. № 10. C. 240-256. https://www.researchgate.net/publication/ 288224764_Tolerance_towards_ambiguity_and_creativity_in_students_and_teachers

4. Kornilov S.A., Grigorenko E.L. What Reading Disability? Evidence for Multiple Latent Profiles of Struggling Readers in a Large Russian Sibpair Sample With at Least One Sibling at Risk for Reading Difficulties // Journal of Learning Disabilities. 2018. № 1. C.434-443. https://journals.sagepub.com/doi/10.1177/0022219417718833

5. Poluyanov Y.A., Davydov V.V. Teacher- student interaction in situations of spontaneous learning independence in primary schoolchildren in art lessons within the system of developmental instruction(Article) // Cultural-Historical Psychology. 2018. № 3. C.5-114. https://psyjournals.ru/en/kip/2018/n3/Poluyanov.shtml

6. Davydov V.V. Vidy obobshchenii v obuchenii [Types of generalizations in learning] // Fundamental and applied researches in practice of leading scientific schools. 2018. № 3. C.170-175. https://www.researchgate.net/ publication/283330238_W_Davydov_-

the_founder_of_significant_scientific_school_and_director_of_the_Psychological_Institute

7. Poluyanov Y. A. Diagnostika obshchego i khudozhestvennogo razvitiya detei po ikh risunkam [The diagnostics of the general and artistic development of children according to their drawings] . International Scientific Journal. 2018. Vol. International Scientific Journal, № 3. P. 5-115.

8. Poluyanov Y. A. Sootnoshenie uchebnoi deyatel'nosti i tvorchestva detei na zanyatiyakh izobrazitel'nym iskusstvom [The correlation of educational activity and creativity of children in classes of visual arts]. Voprosy psikhologii [Questions of Psychology] [Electronic resource]. 2018. № 3. P. 94-102.

9. Rubtsov V. V. Sotsial'nye vzaimodeistviya i obuchenie: kul'turno-istoricheskii kontekst [Social interaction and learning: cultural and historical context]. Cultural-Historical psychology. 2014. № 14. https://psyjournals.ru/en/psyedu/2014/n4/73291.shtml

10. Сиднева А. Н. Проблематика умения учиться в отечественной психологии образования: обзор основных концепций. Психологическая наука и образование. 2017. Т. 22, № 6. https://psyjournals.ru/files/89045/pse_2017_n6_Sidneva.pdf

11. Тверезовська Н., Філіппова Л. Сутність та зміст поняття «педагогічні умови». Харків : Нова педагогічна думка 2009, 2009. 90-92 c.

12. Божович Л. И., Благонадежина Л. В. Изучение мотивации поведения детей и подростков. М : Педагогика, 1972.352 с.

13. Онисюк О. А. Психологічні особливості особистісного розвитку молодшого школяра : автореср. дис. на здобуття наук. ступеня канд. психол.н. : 19.00.07 / . Київ, 2001. 17 с.

14. Пірен М. І. Елітологія підручник. К : Талком,, 2014. 312 с.

15. Люлька Г. А. Самопідготовка вчителя до толерантної взаємодії з молодшими школярами /. Молодий вчений. 2020 . № 5. C. 1-119.

16. Войтович Р. Модернізація державного управління в умовах глобальної інтеграції. Вісн. НАДУ. 2013. № 2. С. 1-24.

17. Артеменко Н. Ф., Гончарук Н. Т. Державна служба-- кадрова політика. монографрія : Управління професіоналізацією кадрів державної служби України: форми, методи, технології, м. Дніпропетровськ, 7-13 November 2012. ДРІДУ : НАДУ, 2012.

18. Liulka G. A. Features of the formation of a tolerant attitude of school and family to children of primary school age. monograph / edited by the authors : Theoretical and practical aspects of the development of the European research space, r. Riga, Latvia, 2020. - (1st edition). - P. 322., 26-29 декабря 2019. Baltija Publishing House : Baltija Publishing House, 2019.

19. Liulka G. A. Self-preparation of teachers for tolerant interaction with younger students. Young scientist. 2020. № 5.

20. Грива О. А. Соціально-педагогічні основи формування толерантності у дітей і молоді в умовах полікультурного середовища. Монографрія: Соціально-педагогічні основи формування толерантності у дітей і молоді в умовах полікультурного середовища, м. Київ, 2-4 Мау 2005. Київ : ПАРАПАН, 2005.

\section{References}

1. Lyapunova , V. (2016). Origins of the development of ideas of tolerance in Ukraine. Cambridge Journal of Education and Science, 1, 6-491. https://elibrary.ru/contents.asp?id=41196356

2. Varetska, O. (2017). Personal and Professional Component of Primary School Teachers' Social Competence: its Development in Postgraduate Education. Personal and Professional Component of Primary School Teachers' Social Competence: its Development in Postgraduate Education, 8, 104-115. http://dspace.pdpu.edu.ua/jspui/handle/123456789/6428

3. Kornilova , T.V., \& Smirnov , S.D. (2018). Tolerance towards ambiguity and creativity in students and teachers . Psychology in Russia: State of the Art ,10, 240-256. URL: https://www.researchgate.net/publication/ 288224764_Tolerance_towards_ambiguity_and_creativity_in_students_and_teachers 
4. Kornilov, S.A., \& Grigorenko, E.L. (2018). What Reading Disability? Evidence for Multiple Latent Profiles of Struggling Readers in a Large Russian Sibpair Sample With at Least One Sibling at Risk for Reading Difficulties. Journal of Learning Disabilities, 1, 434-443. URL: https://journals.sagepub.com/doi/10.1177/0022219417718833

5. Poluyanov, Y.A., \& Davydov , V.V. (2018). Teacher- student interaction in situations of spontaneous learning independence in primary schoolchildren in art lessons within the system of developmental instruction(Article). Cultural-Historical Psychology, 3 , 5-114. URL: https://psyjournals.ru/en/kip/2018/n3/Poluyanov.shtml

6. Davydov, V.V. (2018). Vidy obobshchenii v obuchenii [Types of generalizations in learning]. Fundamental and applied researches in practice of leading scientific schools, 3, 170-175. URL:: https://www.researchgate.net/ publication/283330238_W_Davydov_-

7. Poluyanov, Y.A. (2018). Diagnostika obshchego i khudozhestvennogo razvitiya detei po ikh risunkam [The diagnostics of the general and artistic development of children according to their drawings] . International Scientific Journal, 3, 5-115.

8. Poluyanov YA Sootnoshenie uchebnoi deyatel'nosti i tvorchestva detei na zanyatiyakh izobrazitel'nym iskusstvom [The correlation of educational activity and creativity of children in classes of visual arts] Voprosy psikhologii [Questions of Psychology] URL: chp_2018_n3.pdf. https://psyjournals.ru/files/95405/chp_2018_n3_Poluyanov.pdf

9. Rubtsov, V. V. (2014). Sotsial'nye vzaimodeistviya i obuchenie: kul'turno-istoricheskii kontekst [Social interaction and learning: cultural and historical context]. Cultural-Historical psychology. (14). https://psyjournals.ru/en/psyedu/2014/n4/73291.shtml

10. Sidneva, A. N. (2017). Problematika umeniya uchit'sya $v$ otechestvennoj psixologii obrazovaniya: obzor osnovny` $x$ koncepcij. Psixologicheskaya nauka i obrazovanie, 22(6), 56-67. URL: https://psyjournals.ru/files/89045/ pse_2017_n6_Sidneva.pdf

11. Tverezovska, N., Filippova, L. (2009). Sutnist ta zmist poniattia «pedahohichni umovy»Kharkiv: Nova pedahohichna dumka 2009.

12. Bozhovich, L. I., Blagonadezhina, L. V. (1972). Izuchenie motivacii povedeniya detej i podrostkovM: Pedagogika.

13. Onysiuk, O. A. (2001). Psykholohichni osoblyvosti osobystisnoho rozvytku molodshoho shkoliara. (Candidate of sciences thesis, Kyiv).

14. Piren, M. I. (2014). Elitologiya pidruchnikK: Talkom.

15. Liulka, H. A. (2020). Samopidhotovka vchytelia do tolerantnoi vzaiemodii z molodshymy shkoliaramy I. Molodyi vchenyi, (5), 1119.

16. Voitovych, R. (2013). Modernizatsiia derzhavnoho upravlinnia v umovakh hlobalnoi intehratsii. Visn. NADU, (2), 1-24.

17. Artemenko, N. F., \& Honcharuk, N. T. (2012). Derzhavna sluzhba-- kadrova polityka. In monohrafiia: Upravlinnia profesionalizatsiieiu kadriv derzhavnoi sluzhby Ukrainy: formy, metody, tekhnolohii. DRIDU: NADU.

18. Liulka, G. A. (2020). Features of the formation of a tolerant attitude of school and family to children of primary school age. In monograph / edited by the authors: Theoretical and practical aspects of the development of the European research space. Baltija Publishing House: Baltija Publishing House.

19. Liulka, G. A. (2020). Self-preparation of teachers for tolerant interaction with younger students. Young scientist. (5).

20. Hryva, O. A. (2005). Sotsialno-pedahohichni osnovy formuvannia tolerantnosti u ditei i molodi v umovakh polikulturnoho seredovyshcha. In Monohrafiia: Sotsialno-pedahohichni osnovy formuvannia tolerantnosti u ditei i molodi $v$ umovakh polikulturnoho seredovyshcha. Kyiv: PARAPAN.

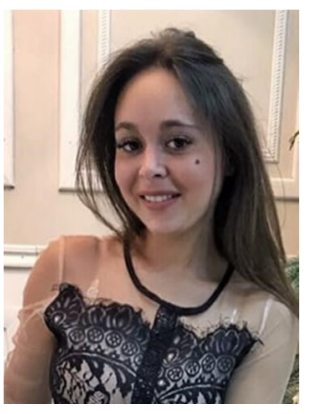

Люлька Ганна Андріївна.

Аспірантка кафедри загальної педагогіки та андрагогіки,

Полтавський національний педагогічний університет імені В. Г. Короленка.

м вул. Остроградського, 2, Полтава, Україна, Індекс. 36003

Тел. (095)-911-7-222. E-mail: annalulka61092@ukr.net

Liulka Hanna Andriivna.

Postgraduate student of the Department of General Pedagogy and Andragogy,

Poltavskyi natsionalnyi pedahohichnyi universytet im. V. H. Korolenka,

vul. Ostrogradskoho, 2, Poltava, Ukraine, Індекс. 36003

Tel. (095)-911-7-222. E-mail: annalulka61092@ukr.net

ORCID: 0000-0001-8915-8426

\section{Citation (APA):}

Liulka H. A. (2020). Substantiation of pedagogical conditions of tolerant attitude of school and family to children of primary school age. Engineering and Educational Technologies, 8 (4), 19-25. doi: https://doi.org/10.30929/2307-9770.2020.08.04.02

\section{Цитування (ДСТУ 8302:2015):}

Люлька Г. А. Обгрунтування педагогічних умов толерантного ставлення школи і сім'ї до дітей молодшого шкільного віку I Інженерні та освітні технології. 2020. Т. 8. № 4. С. 19-25. doi: https://doi.org/10.30929/2307-9770.2020.08.04.02

Обсяг статmі: $\quad$ сторінок - 7 ; умовних друк. аркушів - 1,014. 